\section{Kalimat Sederhana dengan Unsur Pembentuk Predikat Verba pada Bahasa Melayu- Larantuka}

Reyneldis B. Fernandez

Mahasiswa Pascasarjana Prodi Linguistik UGM

Surel: reyneldis.fernandez@mail.ugm.ac.id

INTISARI

Bahasa Melayu Larantuka adalah bahasa di NTT yang belum banyak diketahui. Penelitian bahasa mengenai LRT yang terpublikasi tergolong minim jika dibandingkan dengan bahasa Lamaholot yang lebih identik dengan bahasa-bahasa di Flores Timur. Artikel ini menelaah secara sederhana mengenai konstruksi kalimat sederhana dengan unsur pembentuk predikat verba dalam bahasa Melayu Larantuka; sebagai suatu tinjauan deskriptif awal mengenai bahasa Melayu Larantuka. Data dijaring secara elisit melalui interaksi dengan penutur asli dan kemudian diulas dengan menggunakan teori- teori valensi. Terdapat konstruksi avalent, monovalent, bivalen, dan trivalent dalam kalimat sederhana bahasa Melayu Larantuka. Terlihat pula bahasa Melayu Larantuka merupakan bahasa dengan konstruksi verb medial dan memiliki pola susunan umum berupa SVO.

Kata kunci: basic sentence; Larantuka-Malay; valency; verb predicate

\title{
PENDAHULUAN
}

Polinsky dan Potsdam (2013) menyebutkan bahwa bahasa-bahasa Austronesia memiliki kecenderungan pola verb-initial atau predicate-initial, yakni diawali dengan verba atau predikat. Karenanya pola VSO atau VOS seringkali ditemukan pada bahasa-bahasa Austronesia. Meskipun demikian pada bahasa-bahasa Austronesia lainnya, urutan kata yang umum ditemukan adalah SVO yakni pola verb-medial. Pola ini ditemukan pada bahasa- bahasa Micronesian dan beberapa bahasa Melanesia. Dengan mengesampingkan beberapa bahasa-bahasa di bagian barat Melanesia yang lama mendapatkan pengaruh bahasa-bahasa Papua dan kemudian mengembangkan pola urutan verbfinal, akhirnya disimpulkan bahwa dirasa tidak ada pola urutan kata lain yang dianggap sebagai tipe baku dalam bahasa Austronesia (Lynch, Ross, and Crowley 2002; Crowley 2002).

Dalam tipologi morfologis bahasa secara universal, Comrie (1989) menyebutkan beberapa tipe bahasa, yakni bahasa isolasi, bahasa aglutinasi, bahasa fusional, dan bahasa polisintesis. Masingmasing tipe tersebut akan memiliki kecenderungan karakteristik tersendiri. Misalnya pada bahasa isolasi yang monosilabik, karakteristik yang cenderung ditemukan adalah konstruksi-konstruksi mandiri dimana satu morfem adalah satu kata dan penggunaannya dalam kalimat tidak digabungkan menjadi suatu kata dengan morfem lainnya. Pada bahasa aglutinasi sebuah kata dapat mengandung lebih dari satu morfem dan batas antar morfem tersebut terlihat jelas atau dapat dibedakan dengan jelas. Misalnya saja pada bahasa Inggris, penambahan -s atau -es sebagai pemarka verba jamak adalah suatu fitur yang dapat dikaidahkan dengan pasti sebagai salah satu aturan gramatikal bahasa Inggris. Bahasa dengan tipe fusional juga mengakomodasi adanya lebih dari satu morfem dalam suatu kata, tetapi batas antar morfem tersebut tidak dapat dilihat atau dibedakan dengan jelas. Bahasa Indonesia yang merupakan salah satu varian bahasa Melayu, memiliki kata-kata yang dapat dimasukan dalam tipe bahasa aglutinasi tetapi juga ditemukan kasus-kasus khusus dimana muncul fitur-fitur tipe fusional seperti yang disebutkan di atas. Sedangkan pada Bahasa Melayu Larantuka (selanjutnya dikodefikasi sebagai LRT) diperkirakan lebih banyak ditemukan I kata terdiri atas satu morfem dibandingkan morfem-morfem membentuk satu kata. Karenanya dalam menelaah tentang LRT ini pendekatan yang diambil untuk mencoba mengetahui tipologi bahasanya tidak lepas dari pengetahuan dasar tentang tipologi bahasa dalam empat tipe-tipe tadi.

LRT merupakan anggota rumpun bahasa Austronesia. Bahasa ini disebut sebagai bahasa Nagi oleh penuturnya, masyarakat kota Larantuka, Flores Timur, Nusa Tenggara Timur. LRT merupakan varian bahasa Melayu yang digunakan di kota Larantuka, dan beberapa daerah di sekitarnya. Jika 
ditelusuri secara historis LRT masuk dalam cabang rumpun bahasa Austronesia, yakni keluarga bahasa Nuclear Melayu Polinesia. Disebut demikian karena bahasa-bahasa di dalamnya dianggap membawa konsep inti bahasa Melayu Polinesia yang didalamnya terdapat karakteristik Melayu dan karakteristik Polinesia (Wouk \& Ross, 2002). Dengan jumlah penutur yang terbatas dan minimnya usaha pelestarian secara konstruktif, dokumentasi dan deskripsi LRT dirasa perlu sebagai salah satu usaha untuk pemertahanan LRT sebagai salah satu bahasa daerah yang dimiliki oleh NKRI. Menurut data situs Ethnologue, tercatat kira-kira 20000 penutur asli LRT (Ethnologue, 2007). Dalam kehidupan sehari-hari pemertahanan LRT dilakukan dengan menuturkan antar penutur pada lingkungan informal. Sedangkan pada situasi formal digunakan bahasa Indonesia, dan hingga artikel dan penelitian ini dilakukan tidak terdapat pengajaran secara formal LRT pada situasi formal misalnya saja dimasukan dalam kurikulum pengajaran sekolah dasar, dsb.

Penelitian ini bertujuan untuk mendeskripsikan LRT dari fokus pada konstruksi kalimat sederhana, dimana konstruksi tersebut dibatasi dari predikat dengan unsur pembentuk verba. Unsur pembentuk predikat verba dipilih karena verba merupakan kelas kata yang universal ditemukan pada bahasa-bahasa di dunia. Untuk mencapai tujuan tersebut, dilakukan identifikasi konstruksi kalimat sederhana berdasarkan tingkat atau tipe valensi yang ditemukan dalam konstruksi tersebut.

\section{Gambar 1. Peta Provinsi Nusa Tenggara Timur}

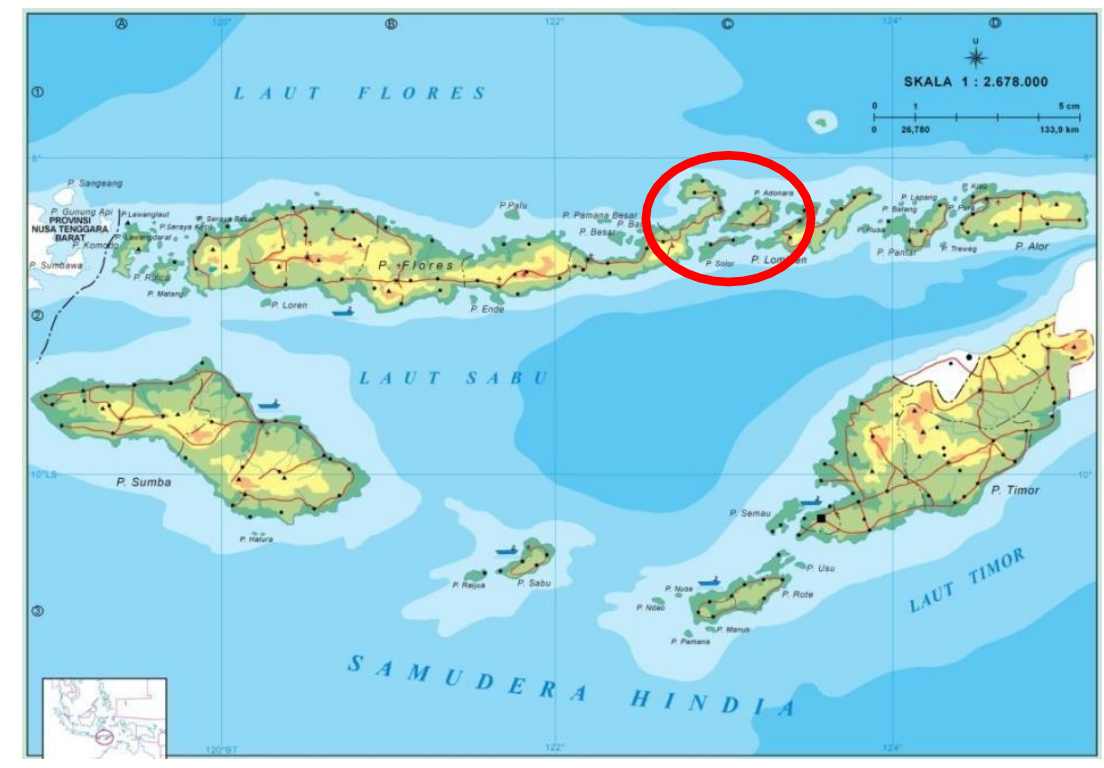

\section{Teori Valensi}

Valensi merupakan suatu istilah yang digunakan untuk menyebut kapasitas suatu verba atau atau kata kerja untuk dirangkaikan dengan argumen atau argumen-argumen (Crystal, 1985). Valensi merupakan suatu cara melihat predikat selain dengan menggunakan voice; yang digunakan dalam mengkaji mengenai struktur klausa ataupun konstruksi kalimat. Menggunakan valensi sebagai alat analisis disarankan bagi bahasa-bahasa yang bentuk- bentuk morfologi argumennya dapat dilihat dengan jelas dan oleh karenanya dapat ditentukan dan dihitung. Karenanya teori valensi kurang dapat bermanfaat pada bahasa-bahasa yang unit argumennya tidak terlihat secara clear-cut atau misalnya sangat bergantung pada intonasi bagaimana unit-unit tersebut dimaknai dengan tona / penekanan (Martin, 2000). Dalam valensi terdapat empat jenis kategorisasi, yakni verba yang tidak memiliki argumen yang disebut zero-place atau AVALENT, verba dengan satu argumen atau argumen subjek yang disebut one-place atau MONOVALENT, verba dengan dua argumen yang disebut two-place atau BIVALENT, serta verba dengan tiga argumen yang disebut three-place atau TRIVALENT.

\section{METODE PENELITIAN}

Metode yang digunakan dalam penelitian ini dibagi dalam tiga tahap, yakni tahap penjaringan/pengumpulan data, tahap analisis data, dan tahap penyajian hasil analisis. Pengumpulan data menggunakan metode intuisi, simak dan teknik catat. Data dijaring dari introspeksi sebagai 
penutur LRT dan interaksi dengan sesama penutur LRT lainnya. Analisis data dilakukan dengan menggunakan metode agih dengan teknik baca markah, teknik ganti, teknik perluas, teknik sisip, dan teknik ubah posisi. Selain itu, metode padan mungkin juga digunakan dengan menggunakan metode translasional terhadap bahasa Indonesia. Penyajian hasil analisis data dilakukan dengan menggunakan pendekatan deskriptif kualitatif.

\section{Sumber Data}

Data penelitian adalah ujaran-ujaran dalam bahasa Melayu-Larantuka yang diperoleh dari introspeksi peneliti sebagai penutur serta dari interaksi dengan sesama penutur di Larantuka, Flores Timur. Data informan ini diambil dengan standar kriteria informan, yang dikondisikan dengan situasi di kota Larantuka, antara lain (I) penduduk asli kelahiran daerah yang diteliti mobilitas rendah, tidak sering pergi keluar desa tempat tinggal; (3) umur antara I5-90 tahun; (4) sehat jasmani dan rohani, termasuk alat ucap pendengarannya; (5) asal-usul informan diusahakan dari desa atau tempat yang diteliti (6) kemampuan informan mengenai bahasa dan dialeknya baik (7) "kemurnian" bahasa informan baik dimana sedikit sekali terpengaruh dari dialek atau bahasa yang dipergunakan di daerah tetangga; (8) berasal dari, lahir, dan besar di tempat yang diteliti. (Ayatrohaedi, 1983).

\section{HASIL DAN PEMBAHASAN}

\section{Konstruksi kalimat sederhana unsur pembentuk verba avalent}

Pada kategori avalent, tidak terdapat argumen dalam kalimat. Pada LRT, temuan yang didapati misalnya adalah sebagai berikut:

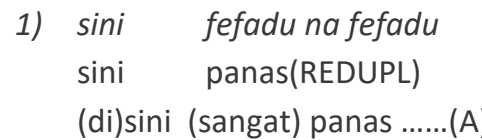

\author{
fefadu na fefadu sini \\ panas(REDUPL) sini \\ (sangat) panas (di)sini ......(B)
}

Pada contoh kalimat (I), dapat dilihat bahwa tidak terdapat argumen pada kalimat tersebut, terdapat bentuk verba keadaan fefadu 'panas' yang juga dalam temuan ini menghadirkan contoh bentuk reduplikasi dalam LRT. Terdapat penambahan na diantara bentuk reduplikasi sempurna kata fefadu yang memiliki makna penyangat pada kata fefadu tersebut. Temuan ini termasuk dalam contoh kalimat deklaratif yang menginformasikan keadaan. Selanjutnya pada contoh ini, ditemukan juga konstruksi sebagai berikut:

2) gempa!

earthquake

(sedang/sementara) gempa

Pada contoh kalimat (2), dapat dilihat bahwa tidak terdapat argumen pada kalimat tersebut, sedangkan didalamnya terdapat modalitas sedang atau sementara yang tidak muncul dalam bentuk morfologi. Dapat dilihat konstruksi ini termasuk pada kalimat deklaratif dan terdapatnya tanda seru pada akhir kalimat sebagai penanda adanya pembeda tona yang bermakna deklaratif pada LRT. Selanjutnya ditemukan juga contoh berikut:

3) sejo beto

sejuk betul

benar-benar sejuk // sangat sejuk

Pada contoh kalimat (3), dapat dilihat bahwa tidak terdapat argumen pada kalimat tersebut, sedangkan pada konstruksinya LRT menempatkan adverbial beto setelah verba, meskipun pada makna semantiknya verba terlekat setelah adverbianya. Dapat dilihat konstruksi ini termasuk pada kalimat deklaratif yang menyatakan keadaan.

Pada temuan-temuan diatas, terlihat bahwa pada kalimat (IA) dan (IB) konstruksi terdiri dari frase verba yang berisi verba dan adverbia berupa keterangan tempat dimana perubahan urutan kata tidak mengubah makna kalimat secara signifikan melainkan memberi nuansa sudut pandang tertentu. Sedangkan pada kalimat (3) konstruksi juga terdiri dari frase verba yang berisi verba dan adverbia (adverbia keadaan), akan tetapi jika urutan kata diubah, kalimat tidak berterima dalam LRT. 


\section{Konstruksi kalimat sederhana unsur pembentuk verba monovalent}

Pada LRT, temuan yang didapati antara lain sebagai berikut:

4) dia menani

dia menais

dia (sedang/sementara) menangis

Pada contoh kalimat (4), terdapat satu argumen pada kalimat tersebut yakni 'dia' sebagai subjek pronomina ketiga tunggal dan 'menani' sebagai verba predikat. Terdapat modalitas sedang yang tidak muncul dalam bentuk morfologi. Temuan ini termasuk dalam contoh kalimat deklaratif yang menginformasikan keadaan.

5) ema pi belanja

ibu pergi belanja

ibu berbelanja

Pada kalimat (5) terdapat konstruksi verba monovalen pada LRT dimana 'pi' digunakan untuk membentuk makna melakukan kegiatan- yang ekuivalen dengan afiksasi ber- pada bahasa Indonesia. 'pi' digunakan sebagai morfem tidak terikat dan diletakan di depan verba predikat utama 'belanja'.

6) doran begoyã

$3 p$ bergoyang

Mereka (sedang)berjoget/berdansa

Pada contoh kalimat (6), dapat dilihat bahwa terdapat satu argumen pada kalimat tersebut yakni 'dorã' sebagai subjek pronomina ketiga jamak dan 'begoyã' sebagai verba predikat. Pada kalimat ini terdapat makna sedang atau tengah-berada-pada-keadaan- pada kata 'begoyã' yang muncul dalam bentuk morfologi dengan morfem terikat be-. Bentuk-bentuk yang serupa seperti ini misalnya pada penggunaan kata 'bejalã'-berjalan, 'belari'-berlari, 'beterea'-berteriak, 'belabo'-berlabuh, dan sebagainya. Meskipun demikian tidak semua kata pada LRT dengan awalan be- memiliki makna demikian. Misalnya pada kalimat (5) meskipun memiliki makna berbelanja, konstruksi dalam LRTnya tidak memunculkan adanya morfem terikat be- tetapi oleh morfem bebas pi yang diletakan sebelum verba utama belanja.

\section{Konstruksi kalimat sederhana unsur pembentuk verbabivalent}

Pada kategori bivalent, terdapat dua argumen dalam kalimat. Karenanya kalimat dengan predikat verba transitif masuk dalam jenis konstruksi ini. Argumen dapat berupa subyek dan obyek. Pada LRT, temuan yang didapati antara lain sebagai berikut:

7) ema masa ae

ibu masak air

ibu menjerang air

Pada contoh kalimat (7), dapat dilihat bahwa terdapat dua argumen pada kalimat tersebut yakni 'ema' sebagai subjek pronomina ketiga tunggal dan 'masa' sebagai verba predikat, dan 'ae' sebagai objek.

8) pa beri kelua doi

3sg beri keluar uang

ayah mengeluarkan uang // ayah melakukan (suatu) pembayaran

Pada contoh kalimat (8), terdapat pula dua argumen pada kalimat tersebut yakni 'pa' sebagai subjek pronomina ketiga tunggal dan 'beri kelua' sebagai frase verba predikat, dan 'doi' sebagai objek. Pada kalimat ini ditemukan kata beri yang muncul di depan verba utama 'kelua' yang memberi makna afiksasi me-kan jika diartikan dalam bahasa Indonesia. Makna ini ditampilkan dalam morfem tidak terikat dan berada di depan verba utama. Temuan- temuan lain yang juga mengandung makna serupa misalnya sebagai berikut: 
9) kita bua mati kompor

buat 1sg mati kompor

saya mematikan kompor

10) kita bua berisi kamar

1sg buat bersih kamar

saya membersihkan kamar

11) ade bua abi tambo

3 sg buat habis lauk

adik menghabiskan lauk

Contoh temuan 9-II termasuk dalam contoh kalimat deklaratif yang menginformasikan keadaan. Pada kalimat ini ditemukan pola dimana kata bua muncul di depan verba utama seperti 'mati', 'abi', dan 'berisi' yang memiliki makna yang ekuivalen dengan makna afiksasi me-kan jika diartikan dalam bahasa Indonesia.

\section{Konstruksi kalimat sederhana unsur pembentuk verba trivalent}

Pada kategori trivalent, terdapat tiga argumen dalam kalimat. Karenanya kalimat dengan predikat verba transitif masuk dalam jenis konstruksi ini. Argumen dapat berupa subyek, obyek langsung dan obyek tidak langsung. Pada LRT, temuan yang didapati memiliki tiga argumen berupa subyek, obyek langsung dan obyek tidak langsung misalnya sebagai berikut:

12) ema masa beri tora rumpu rampe

ibu masak untuk kami/kita rumpurampe (nama masakan sayuran)

ibu memasakkan kami/kita sayur rumpu rampe // ibu memasak sayur rumpu rampe untuk kami/kita

Pada contoh kalimat (I2), terdapat tiga argumen pada kalimat tersebut yakni 'ema' sebagai subjek pronomina ketiga tunggal, 'rumpu rampe' sebagai objek langsung dan 'tora' sebagai objek tidak langsung. Pada kalimat ini ditemukan verba berangkai yakni 'masa beri' yang muncul sebagai pembentuk verba dimana kata 'beri' memiliki makna serupa dengan afiksasi me-kan jika diartikan dalam bahasa Indonesia. Kalimat ini merupakan kalimat benefaktif dimana agent adalah subjek kalimat, yakni 'ema' dan patient adalah objek tidak langsung dalam kalimat tersebut yakni 'tora'. Juga tertangkap dalam temuan ini adalah LRT tidak memiliki pembeda untuk kata ganti orang pertama jamak inklusif maupun eksklusif. LRT menggunakan kata 'tora' sebagai pronomina pertama jamak, sedangkan makna inklusif maupun ekslusif biasanya akan terlihat jika dari konteks wacana ujaran keseluruhan. Temuan lain pada kategori ini adalah sebagai berikut:

13) tata beli beri ade baju

kakak beli baju untuk adik

kakak membelikan adik baju

14) ade bua beri tata kue

adik membuat kue untuk kakak

adik membuatkan kakak kue

Pada contoh kalimat (I3) dan (I4), terdapat data yang juga menunjukan adanya tiga argumen dengan konstruksi yang serupa. Terdapat agent yang terletak pada posisi subjek di awal kalimat, 'beri' yang muncul setelah verba utama yang memberikan makna benefaktif pada kalimat tersebut, objek tidak langsung yang juga memiliki peran patient muncul segera setelahnya dan kemudian diikuti dengan objek langsung. 


\section{KESIMPULAN}

Pada konstruksi kalimat sederhana bahasa Melayu-Larantuka (LRT) bentuk-bentuk argumen dapat terlihat dengan jelas. Dengan morfem verba yang juga terlihat jelas, dapat digunakan valensi untuk menggambarkan konstruksi kalimat sederhana pada LRT. Penelitian menemukan terdapat konstruksi avalent, monovalent, bivalen, dan trivalent dalam kalimat sederhana bahasa Melayu Larantuka (LRT) dengan unsur pembentuk predikat verba. Dari tiap-tiap temuan data yang terjaring dan teranalisis, terlihat pula bahwa bahasa Melayu Larantuka merupakan bahasa dengan kecenderungan konstruksi verb medial dan memiliki pola susunan umum berupa SVO. Pada kalimat intransitif yang juga kalimat monovalent ditemukan bentuk morfem terikat be- yang memiliki makna sedang melakukan- atau tengah melakukan. meskipun demikian terdapat juga verba monovalen dengan makna serupa yang morfemnya menggunakan morfem bebas 'pi' yang diletakkan di depan verba utama. Pada kalimat transitif bivalent dan ditransitif trivalent, ditemukan beberapa pola berbeda dimana verba-verba tertentu seperti 'beri', dan 'bua' yang menjadi produktif dalam tingkat kemunculannya yang terangkai dengan verba lain (verba utama) untuk menggambarkan makna benefaktif, ataupun agent/patient dalam konstruksi kalimat.

\section{BIOGRAFI}

Penulis bernama lengkap Reyneldis Belladona Fernandez ini memperoleh dua gelar sarjananya pada jurusan Ilmu Komputer dan program studi Pendidikan Bahasa Inggris di Universitas Nusa Cendana. Saat tulisan ini dibuat, penulis tengah menempuh pendidikan magisternya di program studi Magister Ilmu Linguistik di Fakultas IImu Budaya Universitas Gadjah Mada. Tulisan ini merupakan bagian dari penelitian tesis penulis mengenai Bahasa Melayu Larantuka.

\section{DAFTAR PUSTAKA}

Ayatrohaedi, 1983. Dialektologi Sebuah Pengantar. Jakarta: Pusat Pembinaan dan Pengembangan Bahasa Departemen Pendidikan dan Kebudayaan

Comrie, Bernard. 1989. Language Universals and Linguistic Typology. Great BritainBilling \& Sons Ltd.

Crowley, Terry 2002. Serial verbs in Oceanic: A descriptive typology. Oxford: Oxford University Press.

Crystal, D. 1985. A dictionary of linguistics and phonetics, 2nd edn. Oxford: Basil Blackwell. Lynch, John, Malcolm Ross, and Terry Crowley (eds.) 2002. The Oceanic languages. Richmond: Curzon Press.

Ethnologue, 2007. Ethnologue: Languages of the World. https://www.ethnologue.com/language/lrt. Dikunjungi pada 27 Juli 2019.

Martin, Jack B., 2000. Creek Voice: Beyond Valency. In Changing Valency, ed. by R. M. W. Dixon \& Alexandra Y. Aikhenvald 375-403. Cambridge: Cambridge University Press.

Polinsky, Maria and Eric Potsdam. 2013. Austronesian syntax in Bill Palmer (ed.) Oceania. Berlin: Mouton

Wouk, Fay and Malcolm Ross. 2002. The History and Typology of Western Austronesian Voice Systems. Canberra : Pacific Linguistics, Research School of Pacific and Asian Studies, Australian National Universiy 